いの加，2）充塨位圆を顔面神経管上に招き，生理的 な大きさにすることはないか. 応答 1)瘦孔, 硬膜露出があっても，充填は行う，真珠腫残存の可能 性があるものはしない，2）軽い外耳道桩大はかまわ
ない，要は上皮の連続性上自律作用の確保である。 質問 湯浅 涼(東北労狄)。骨片を用いずアパタイト を用いる理由. 応答確実な充填を行うため。異 物とは考えておらず， bioactiveな素材と思っている。

\title{
13. 真珠腫に対する耳小骨保存手術
}

\author{
山口龍二・青木 基・野原 修・梅澤祐二・本多芳男（慈大）
}

真珠腫に対する鼓室形成術では，まず真珠腫の除去 を行い, 伝音系を再建し聴力の改善を図るのが一般的 てある。この際，外耳道を保存して真珠腫の清掃を行 うことは困難で，多くの場合砧骨や随骨頭を除去する ことになる、次いで耳小骨の再建を行うが, 術後の恥 力は低下することが多い。そこで, 最近我々の教室で は聴力低下の軽い真珠腫例ことに弛緩部型真珠腫に対 して, 後述の Transmeatal attico-antrotomy を行い 耳小骨連鎖を保存する真珠腫手術を行っているので, ビデオを供覧し紹介した。

術式 耳後皮盧切開に続いて経外耳道的に上鼓室側 壁より外耳道後壁の一部を除去して真珠腫組織を清掃 する。上・中鼓室間の交通 (aeration) をつけるように 開放する、弛緩部型真珠腫は概して耳小骨の外側に存 在するのて，この操作によって耳小霄を保存した真珠 腫の完全清掃は可能である.上鼓室内側粘膜亚びに鼓 膜緊張部を保存し，傊した鼓膜上部を筋膜で再建す る。その外側に耳介軟骨板を用いて上鼓室外唰壁を再 建する。これらの再建に際して，フィブリン糊を用い ることにより本術式の操作は容易かつ確実になった。

考按ここに供覽したような transmeatal atticotomy は古くから行われているが，本法（図）で は軟骨板を筋膜の外側に置いて側壁の形成を行うのが 特幑で, 術後外耳道は生理的であり, 新鼓膜の位置が 安定している。術後の乳乫腔が過大にならず，上鼓室 への通気性は良く，粘膜を保存しているので肉芽の形

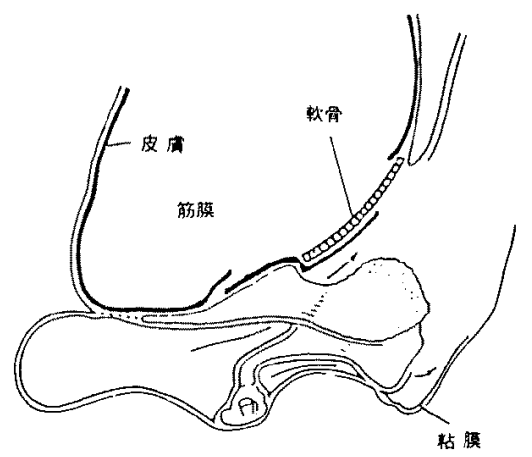

成が少なく，術後の鼓膜の楩凹が起こりにくいと考之 ている，耳小骨は保存するので, 術後の聴力は良好で ある. 質問 新川敦(東海大). 1) Mastoid内 の肉芽の処理はどうしているか．2）皮膚欠損部の上 皮化に時間がかかっているようであるが，感染の心配 はないのか。応答 1) コレステリン肉芽腫の残 存ないことを術中確認している，2）術後上皮化まで の間に，感染などのトラブルは，経験していない。 質問 瀧本 勲(愛知医大)。軟骨板は症例により薄く 弱くなるが,耳管機能を考えて本操作をやるか. 応 答 耳管機能の良好例に，供覽した手術法を行ってい る。

\section{4. 外来での簡易な鼓膜形成術}

$$
\text { ーフィブリン糊を用いた接着法一 }
$$

\section{湯浅 涼・西條 茂・末武光子・欠畑誠治・金子}

目的鼓膜穿孔を外来通院で閉鎖しようとする試み は従来から多くの報告がみられるが，その術後成績は 必ずしも良好ではなかった。今回報告する方法は自家 組織（耳後部皮下結合織あるいは側頭筋膜）をフィブ リン糊で接着する方法で, 過去 1 年 6 力月（1988年11 月〜1990年 4 月)の間に350耳に対して施行された。 そ の結果は従来の方法に比べ，極めて渾足す心゙き結果を 得たので, 術式を中心に, 術㣪 3 力月以上経過した 255 耳の術後成績を報告した。

\section{豊・神林潤一 (東北労災) 松谷子(仙台赤十字)}

対象 1988年11月から1990年4月までの1年6力月 間に鼓膜緊張部穿孔例 $350 耳$ 耳対して行われた。年齢は $7 \sim 79$ 歳で, 鼓膜穿孔期問は 2 力月〜 50 年, 疾患別で は慢性中耳炎が $81 \%$, 外傷性鼓膜裂傷 $10 \%$, 鼓膜切開・ チェ一ブ插入後 $9 \%$ あ゙ある。

手術手技 中心性穿孔に対しては残存鼓膜に対し鼓 膜麻酔液のみの局部麻舅で，辺緑性穿孔（後部）に対 しては0.5\%リドカインの浸潤麻酔を用いる.穿孔縁を 切離，鉗除し接着部位の創面新鮮化を行う。耳後部皮 
下結合織あるいは側頭筋膜を採取し，穿孔面積の約 2 倍にトリミングし圧迫する、移植材料を穿孔裹面に固 定する underlay 法であるが，移植材料が新鮮化され た穿孔緑に密着するよう材料を十分に引き出すことが 重要なボイントとなる。材料が適切な位置に安定した ら、フイブリン糊を1谪ずつ接合部位に滴下し，固定 する，過剩な糊は後日新生鼓膜上に固着し好ましくな い, 辺縁性穿孔で, 後部に「のりしろ」が欠如する場 合には, 外耳道後壁皮膚を一部切開・㓦離し, 移植材 料を皮膚・骨面間に挿入する，術後は一般に外耳道内 にパッキングは行わないため, 術直後に改善された聴 力がそのまま持続する。そのため, 雨側同日手術や, 反対側が高度難悖耳に対しても施行可能である点は大 きな特長である。

術後成績 術後 3 力月以上経過した 255 耳のうち, 術 後再穿孔をきたし，その後も穿孔が持続しているもの
(再穿孔のため従来の方法で再手術したものも含む)は 37 耳 $(14.5 \%)$ みられた。この再穿孔率は術開発頭初 の50耳までは $26.6 \%$ と高率であったが，その後は10\% 前後に低下した，術後聴力は術直後にパッチレベル近 くまで改善され，その後更に改善される。術後気導恥 力が術前骨導值を上まわるものが36\%みられた。術後 聴力悪化例は全くみられなかった。質問・追加 阪 東和一郎(北九州市).1) 本手術症例は耳の全手術例 の何\%位か．私の経験で $50 \%$ を越える．2）局所麻 酔はツェンテールのみで不十分で, 外耳道への注射麻 酔が必要な場合もある，3）接着剤 Beriplast P と Ti シールは使用上差はあるか。応答 1) 真珠腫・ 耳小骨障害例等は本法の適応外である。他の過半数は 本法が行われた，2）辺縁性穿孔で外耳道切開を行う 場合は局麻が必要.3） 2 つの製品にはフィブリン溶 解上差がある。ベリプフストが溶解が容易。

\section{5. カップピストン使用によるアブミ骨手術}

$$
\text { 小寺一興・大平泰正・大蔵目一（帝京大） }
$$

はじめに 耳硬化症の初期や中耳奇形では, アブミ 骨手術でアブミ骨の上部構造を除去するときに，アブ ミ骨全体が底板を含めて一塊として除去されてしまう ことがある。このような場合に，手術終了後に早期に 外リンパの漏出を停止させるためには，卵円空を完全 に閉鎖させる衍式が望ましい。われわれは，アブミ骨 が一塊として除去された例にたいして，卵円空を骨膜 で閉鎖しカップピストンを使用するアブミ骨手徒を行 い，良好な術後成績をえている，本報告では，手術手 技をビデオで供覧した。

手術手技 耳内から耳前部に皮膚切開を执き，外耳 道後上方を拡大し，顔面神経水平部と錐体隆起を明視 下に挹き，アブミ骨全体を明視下に扔く，鼓索神経を ツチ骨頸部でソチ骨より剥離し反転させた鼓膜側に奇 せる。つぎにブミ骨筋腱を切断する，以上の手技は すべてのアブミ骨で共通としている．アブミ骨上部構 造の骨折を試みたときにアブミ骨全体が動く場合に は,アブミ骨の操作を中断し, 薄い骨膜を採取する。 大きさはほほ $1 \mathrm{~cm}$ 四方とする。つぎにアブミ骨を外側 方向に引いて除去する。アブミ骨底板上の粘膜断端よ り出血がおこるが血液の吸引は安全な範囲とする。前 に採取した骨膜で卵円空を閉鎖する。ピストンの先端 を骨膜の上から卵可空の中央方向人押し，キヌ夕骨の 長脚をフックで外側へ引き，豆状乫起をカップにはめ 込み，カップピストンを固定する. ジェルフォームを 骨膜と鼓膜の間に軽くつめ, 鼓膜を戻して外耳道をパ
ックする。

成績 最近 5 年間に当施設で行ったアブミ骨手術79 耳のうち，当術式を行った症例は10例であった。全例 で術後経過は良好で，平均気導聴力（三分法）は平均 $38 \mathrm{~dB}$ 改善し, 術後骨導に対する気骨導差は平均 $8 \mathrm{~dB}$ であった．また，術後のめまい感の持続はピストンワ イヤー使用例と比べて差がなかった。

考察 アブミ骨手術で内耳障害をおこし得る原因は アブミ骨底板の除去に伴う外科的侵彆と, 術後の外リ ンパの漏出の持続であろう。本報告の術式は，外リン パの漏出を術直後から停止させることができるので, 安全性の高い術式であるう。質問 熊川孝三（虎 の門).アブミ骨の不完全固着症例でもアブミ骨脚切断 剪を用いることで底板を残せる，そして注意深く行え ば, small fenestra stapedectomy で対応できると考え る. 応答 脚を切断することは行っていない. 中 耳奇形ではとくに，アブミ骨が底板を含めてとれるこ とは，一定の頻度で起こると思う。私の施設では(10， 79例で） 13\%であった。質問 湊川（兵庫医大）。 1）閉鎖膜に骨膜を使う理由. 2) 閉鎖膜は大きすぎ ないか.3）ゼルフォームによる固定は必要か。沁 答 1) 骨膜使用の理由は術野で簡単にとれるから で，原法では静脈弁を使用している，2）骨膜の大き さ跓，ピストン固定時のズレを考えると十分大きい必 要がある．3）最後のジェルフォームは不要かもしれ ない. 